\title{
Ni-718 superalloy foam processed by powder space-holder technique: Microstructural and mechanical characterization
}

\author{
G. Timac ${ }^{1}$, H. O. Gulsoy ${ }^{2,3 *}$ \\ ${ }^{1}$ Marmara University, Inst. Graduate Studies Pure and Applied Sci., 34722 Göztepe, Istanbul, Turkey \\ ${ }^{2}$ Marmara University, Technology Faculty, Metallurgy and Material Eng., 34722 Göztepe, Istanbul, Turkey \\ ${ }^{3}$ Marmara University, Nanotechnology \& Biomaterials Applied and Research Centre, 34722 Göztepe, Istanbul, Turkey
}

Received 5 April 2016, received in revised form 11 September 2016, accepted 12 September 2016

\begin{abstract}
In this work, porous Ni-718 superalloys were produced by use of a water soluble pore forming agent before sintering. Carbamide particles were used as the space-holder material. After mixing and compaction, the space-holder particles were extracted using hot water leaching over a range of temperatures. The porous green parts were thermally debound to remove the paraffin wax under a pure argon atmosphere and then sintered at high vacuum. The effects of the volume fraction of space-holder particles on density and porosity were investigated. Microstructures were captured using optical and scanning electron microscopy. Also, compression tests were conducted on the sintered samples.
\end{abstract}

K e y w or d s: superalloys, metal foam, sintering

\section{Introduction}

Metallic materials with controlled porosity are widely used in filtration, wicks, heat pipes, sound attenuation abradable seals, and flow control devices. Even lower densities are being promoted for energy absorption and applications requiring tailored mechanical, thermal, acoustic, and conduction properties [15]. Foamed materials are still expensive, so their use is restricted to aerospace applications $[1,7]$. Ni-718 superalloy with proper development of the strength to weight ratio could be an alternative to other superalloys and foam materials [3-9]. Nickel-based superalloys are an unusual group of metallic materials, showing an extraordinary combination of high-temperature strength, toughness, and surface stability in corrosive or oxidative environments [10,11].

Given such superior characteristics, they are very important materials for high-temperature applications such as aerospace and power generation industries [11]. One of the Ni-based superalloys, which has been most successfully applied in the engineering applications, is Ni-718 alloy [12]. Ni-718 is designed to initially gain high-temperature strength by solid solution hardening brought about by $\mathrm{Mo}$ and $\mathrm{Nb}$ elements in $\mathrm{Ni}-\mathrm{Cr}$ matrix. However, Ni-718 was designed to gain strength using solid solution initially. It is seen that the intermetallic phases and carbides precipitate through aging treatments performed in the temperature max. $720^{\circ} \mathrm{C}$ $[13,14]$.

Metallic or ceramic foam materials (open-cell and close-cell) with a volume fraction of pores in the range of $5-80 \%$ can be produced by different techniques (casting, sputter deposition, liquid-state processes GASAR, and powder metallurgy - PM) [1-5]. Pore former and PM with space-holder techniques have previously been demonstrated in the fabrication of other metallic and ceramic parts as well as stainless steel and low strength steel [14-16]. With proper selection of the sintering cycle, the small particles bind, but the large intentional pores remain. Thus, the process is composed of four sequential steps: (1) mixing of the powder, polymeric molding binder, and space-holder particles; (2) compacting or shaping the mixture, for example by axial compression; (3) removing the binder phase and dissolving the space-holder particles without damaging the particle structure usually by a thermal step, and (4) sintering the structure to induce strong particle binding without densification of the pores remaining from the space-holder particles [9].

*Corresponding author: tel.: +90-216-3365770-1322; fax: +90-216-3378987; e-mail address: ogulsoy@marmara.edu.tr 
Table 1. Chemical composition of Ni-718 superalloy powder (wt.\%)

\begin{tabular}{ccccccccc}
\hline $\mathrm{Ni}$ & $\mathrm{Cr}$ & $\mathrm{Fe}$ & $\mathrm{Nb}$ & $\mathrm{Mo}$ & $\mathrm{Al}$ & $\mathrm{Ti}$ & $\mathrm{C}$ & $\mathrm{Si}$ \\
\hline Bal. & $17-20$ & $14-16$ & $4.7-5.5$ & $2.8-3.3$ & $0.2-0.8$ & $0.6-1.1$ & $0.03-0.06$ & 0.22 \\
\hline
\end{tabular}

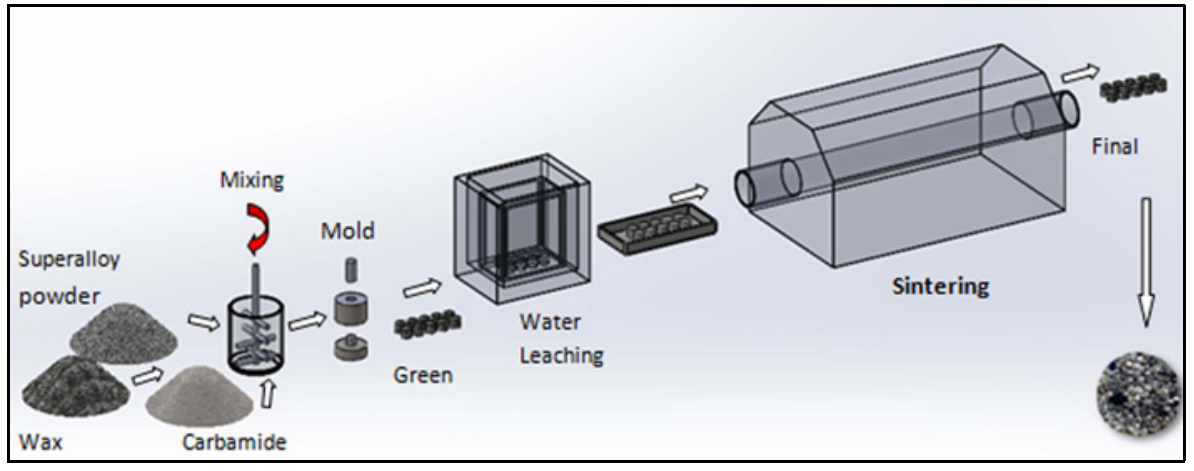

Fig. 1. Processing steps of production of the porous Ni-718 superalloy.

In the approach, the initial size and content of the space-holder particles provide the key control over the porosity, pore size, and pore connectivity [17-20].

Several pore forming agents have been used in the past, including ice, salt, polymers, and volatile compounds such as camphor and ammonium bicarbonate $\left(\left(\mathrm{NH}_{4}\right) \mathrm{HCO}_{3}\right)[15,18]$. These have been combined with several metallic powders including aluminum, titanium, stainless steel, and nickel superalloys. Both carbamide $\left(\left(\mathrm{NH}_{2}\right) 2 \mathrm{CO}\right.$ also known as urea) and ammonium bicarbonate have been used with thermal extraction by heating below $200^{\circ} \mathrm{C}$; however, there are negative factors from the vapor release from these pore-forming species $[9,15,17]$. There exist a few reports on superalloy foams because of the difficulty of processing these high-melting alloys into foams. After thermal decomposition of the template, the foams, with relative densities of $<3 \%$, were pressureless sintered or transient liquid-phase sintered. No mechanical properties were presented. Sypeck et al. [20] used hollow Ni-718 spheres created as a by-product of gas atomization. These spheres, with a size between 0.36 and $2 \mathrm{~mm}$, were sintered for $24 \mathrm{~h}$ at $1265^{\circ} \mathrm{C}$ into foams with a relative density of $30-34 \%$. Compressive mechanical properties were reported at ambient temperature, but not at elevated temperature. The creep behavior of the superalloy foams was measured between 650 and $825^{\circ} \mathrm{C}$ in the stress range of $0.1-0.3 \mathrm{MPa}$.

In this work, porous Ni-718 superalloy was produced by the use of a water-soluble space-holder material to sintering. Carbamide particles were used as the space-holder material. After compaction, the spaceholder particles were extracted by hot water leaching over a range of temperatures. The porous green parts were subsequently thermally debound to remove the paraffin wax, and subsequently sintered under vac- uum. The effect of the volume fraction of space-holder particles on density and porosity of the sintered samples was investigated. Microstructures were captured using optical microscopy (OM) and scanning electron microscopy (SEM). Pore size was quantified using image analysis software integral to the SEM. Also, compression tests were conducted on the sintered samples.

\section{Experimental procedure}

A schematic illustration of the production process is given in Fig. 1. The powder was gas atomized Ni-718 superalloy. It was obtained from Sandvik Osprey Metals Ltd. with a reported chemistry in Table 1. The SEM image of the powder is given in Fig. 2a. To determine particle size distribution of the starting powder mastersizer analysis was performed on Malvern Mastersizer device. The cumulative size distribution at the $D_{10}, D_{50}$, and $D_{90}$ percent points corresponds to particle sizes of $D_{10}=4.5 \mu \mathrm{m}, D_{50}=$ $11.9 \mu \mathrm{m}$, and $D_{90}=26.2 \mu \mathrm{m}$. Carbamide had a density of $1.34 \mathrm{~g} \mathrm{~cm}^{-3}$, melting temperature of $133^{\circ} \mathrm{C}$, and solubility in water at $20^{\circ} \mathrm{C}$ of more than $1000 \mathrm{~g} \mathrm{~L}^{-1}$. It was prepared as an irregular particle in a size range from 1400 to $1800 \mu \mathrm{m}$. The SEM image of the carbamide particles is given in Fig. 2b. It is observed from Figs. 2a and 2b that the particle shape of alloy $\mathrm{Ni}-718$ powders and carbamide particles is spherical.

The binder ingredient for green strength was paraffin wax with a melting range from 123 to $125^{\circ} \mathrm{C}$. It was used at 2 wt.\% based on the Ni-718 superalloy mass. Initially, the Ni-718 powder and paraffin wax were mixed for $30 \mathrm{~min}$ using a double-cone mixer heated to $100{ }^{\circ} \mathrm{C}$ to melt the wax. The Ni-718 and carbamide particle ratios were adjusted to give 60 and 80 vol. $\%$ 

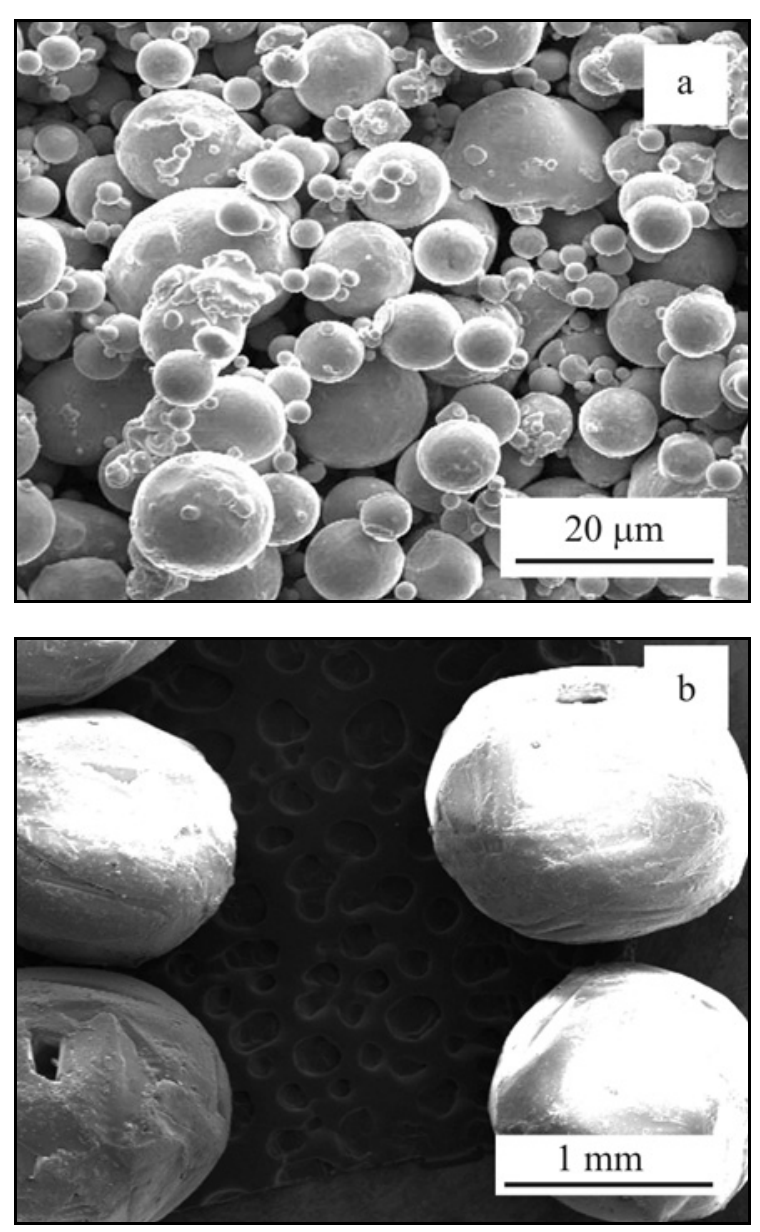

Fig. 2. SEM of Ni-718 superalloy powder (a) and carbamide particles (b).

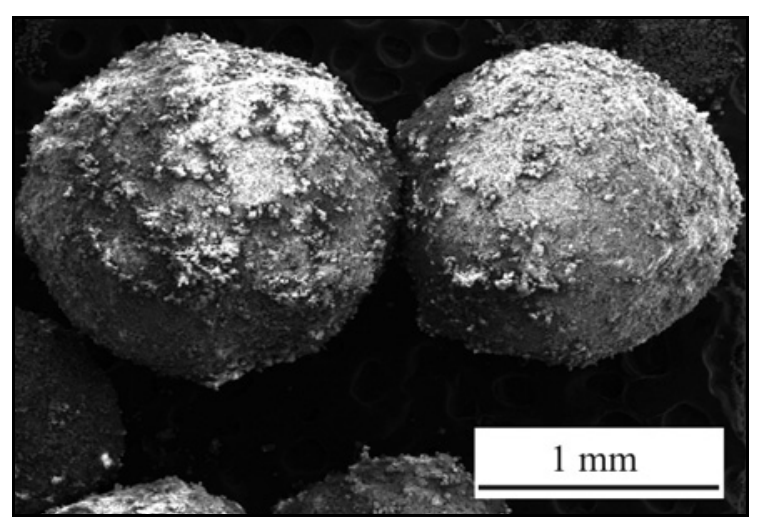

Fig. 3. SEM of coated carbamide particles with Ni-718 superalloy powder.

carbamide particles and paraffin wax in the samples. Mixing of the waxed Ni-718 and carbamide powders was performed in a Turbula mixer for $1 \mathrm{~h}$. SEM of the coated carbamide particles with $\mathrm{Ni}-718$ powder is given in Fig. 3.

The mixtures were compacted at $100 \mathrm{MPa}$ into (a) $60 \%$

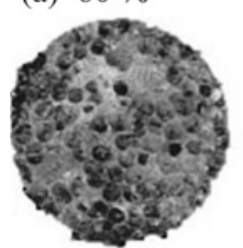

(b) $70 \%$

(c) $80 \%$

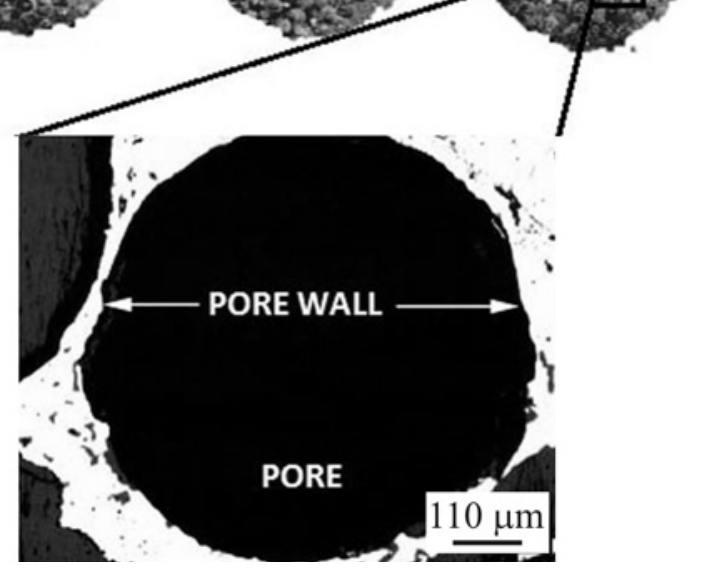

Fig. 4. Macroscopic morphology of sintered Ni-718 superalloy samples from surface $60 \%$ (a), $70 \%$ (b), and $80 \%$ carbamide (c).

cylinders with a diameter of $19 \mathrm{~mm}$ and height of $20 \mathrm{~mm}$. The green samples were held at 30 and $40^{\circ} \mathrm{C}$ for times ranging from 1 to $6 \mathrm{~h}$ in distilled water. The paraffin wax was thermally removed as a part of the sintering cycle, which consisted of heating step-by-step at $1^{\circ} \mathrm{C} \mathrm{min}{ }^{-1}$ to $600^{\circ} \mathrm{C}$ with a $6 \mathrm{~h}$ hold, followed by heating at $5^{\circ} \mathrm{C} \min ^{-1}$ to $700^{\circ} \mathrm{C}$ for $1 \mathrm{~h}$ to pre-sinter the compacts. This was performed in high purity argon. Subsequent final sintering relied on a heating rate of $10^{\circ} \mathrm{C} \mathrm{min}^{-1}$ to $1265^{\circ} \mathrm{C}$ for $1 \mathrm{~h}$ under vacuum $\left(10^{-3} \mathrm{~Pa}\right)$. The sintered samples were solution treated at $980^{\circ} \mathrm{C}$ for an hour as specified in the literature for alloy Ni-718 [21] and then cooled down in the water. The solution treated samples were aged at $720^{\circ} \mathrm{C}$ for different times and then at $620^{\circ} \mathrm{C}$ for $8 \mathrm{~h}$. The density was calculated by dividing the mass of the compact by its volume, which was calculated from physical dimensions.

Samples were mounted in epoxy and polished as standard metallographic procedures. Microstructures were obtained via OM and SEM after etching. Compression tests were performed at a crosshead speed of $1 \mathrm{~mm} \mathrm{~min}^{-1}$ (Zwick, Roell-Z250 materials testing system). This device was calibrated using the EN ISO 7500-1 standards. At least three specimens were tested under the same conditions to assess repeatability, and average values were used.

\section{Results and discussion}

Ni-718 superalloy samples with porosities ranging 

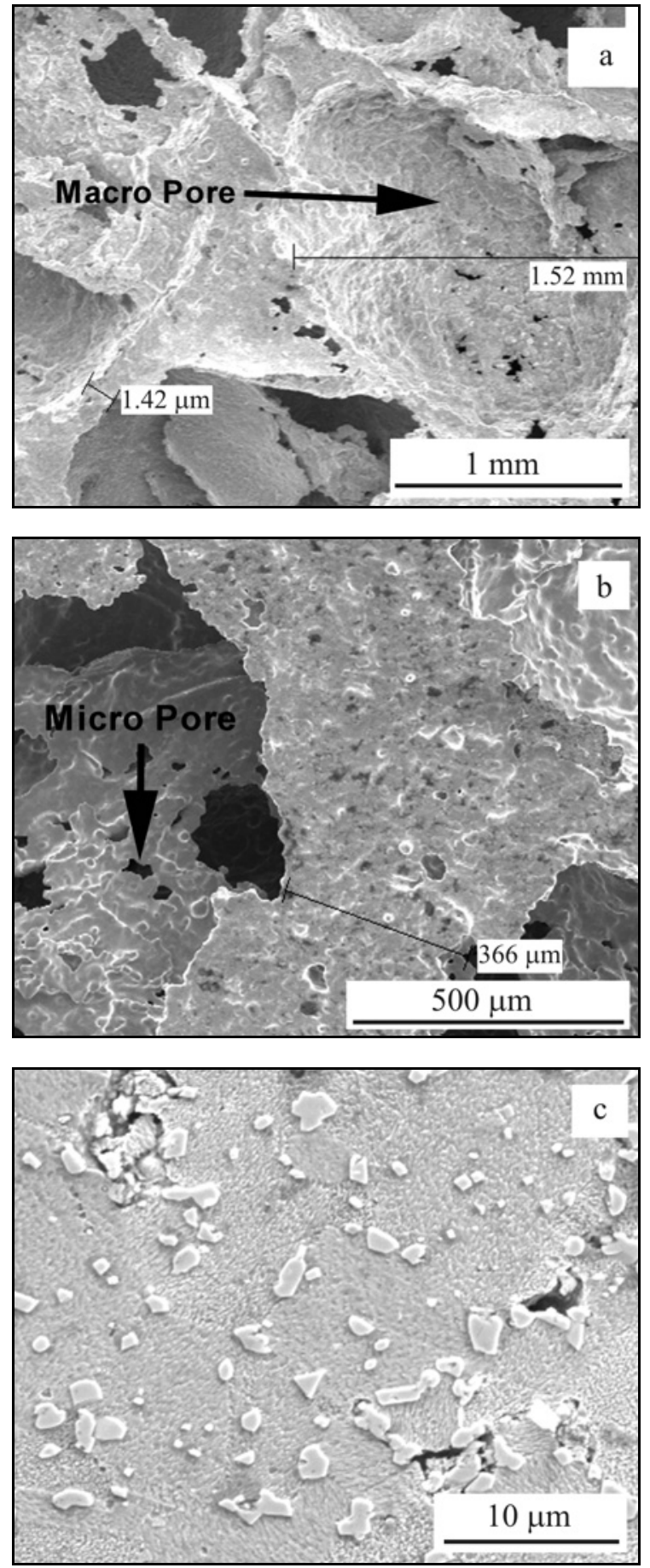

Fig. 5. SEM micrographs of Ni-718 superalloy foam for 80 vol.\% carbamide: on the surface of porous samples (a), (b); on the pore wall (c).

between 60,70 , and $80 \%$ were successfully produced. As the carbamide particle content increased, the sintered density decreased, and the porosity increased in all samples. As expected from the $1265^{\circ} \mathrm{C}$ sintering temperature (slightly low for this material and particle size), the sintered density was $8.2 \mathrm{~g} \mathrm{~cm}^{-3}$ (roughly
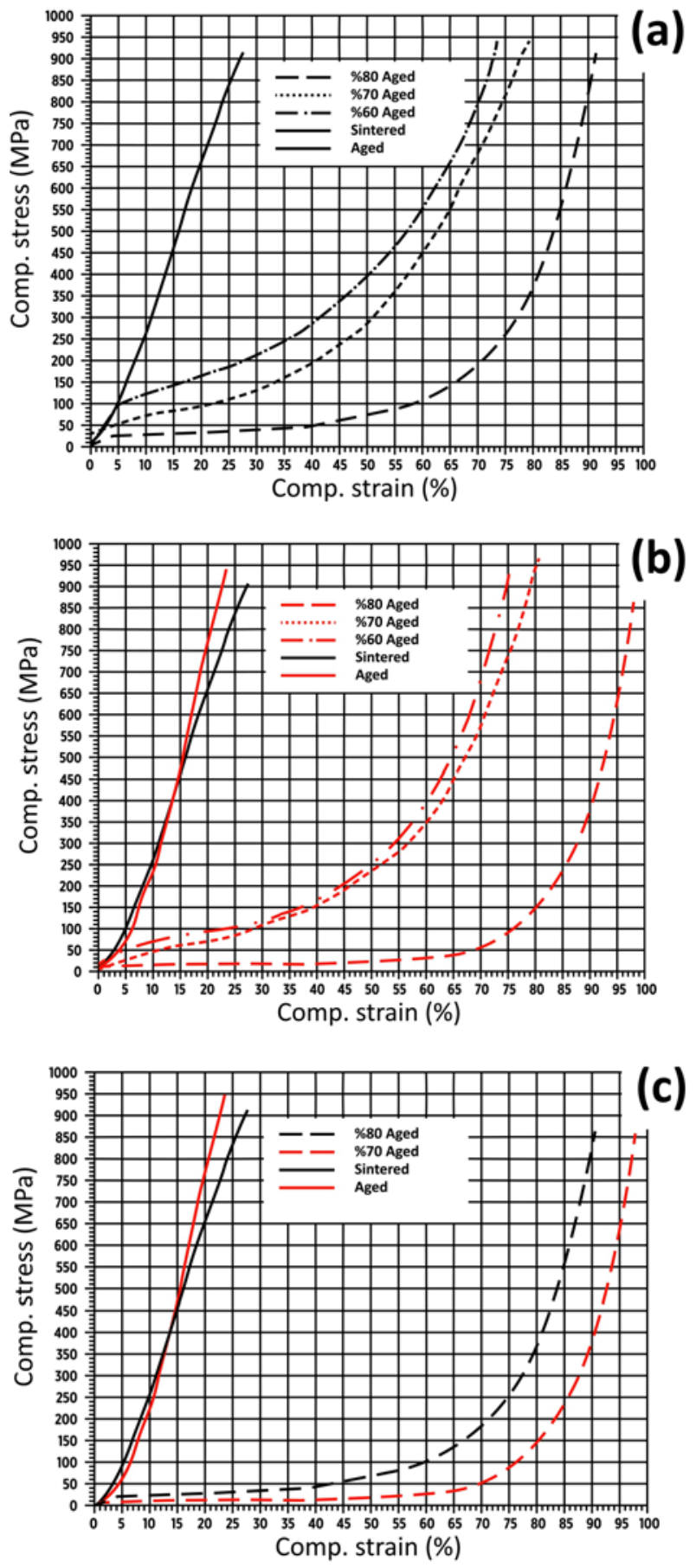

Fig. 6. Compressive stress-strain curves of porous Ni-718 superalloy samples with $60-80$ vol.\% carbamide space-holder sintered samples (a), aged samples (b), and comparison of sintered and aged samples for $80 \mathrm{vol} . \%$ (c).

$97 \%$ dense). Sintered densities of 4.0 and $2.5 \mathrm{~g} \mathrm{~cm}^{-3}$ were obtained with 60 and 80 vol.\% carbamide particles additions, respectively. Figure 4 shows the sintered and aged samples having 60, 70, and 80 vol.\% porosity. Optical micrographs of the cell wall of foam are also shown. In all samples, the morphology of the 
Tab le 2. Properties of Ni-718 sintered-aged samples processed by the space-holder technique

\begin{tabular}{|c|c|c|c|c|c|c|c|}
\hline $\begin{array}{l}\text { Sintering } \\
\text { conditions }\end{array}$ & $\begin{array}{c}\text { Heat } \\
\text { treatment } \\
\text { conditions }\end{array}$ & $\begin{array}{l}\text { Fraction of } \\
\text { carbamide } \\
\text { (vol. } \%)\end{array}$ & $\begin{array}{l}\text { Sintered } \\
\text { density } \\
\left(\mathrm{g} \mathrm{cm}^{-3}\right)\end{array}$ & $\begin{array}{c}\text { Compressive } \\
\text { strain at } \\
600 \mathrm{MPa} \\
(\%)\end{array}$ & $\begin{array}{c}\text { Compressive } \\
\text { strain at } \\
950 \mathrm{MPa} \\
(\%)\end{array}$ & $\begin{array}{c}\text { Compressive } \\
\text { stress at } 20 \% \\
\text { strain } \\
(\mathrm{MPa})\end{array}$ & $\begin{array}{c}\text { Compressive } \\
\text { stress at } 50 \% \\
\text { strain } \\
(\mathrm{MPa})\end{array}$ \\
\hline $1265^{\circ} \mathrm{C}-1 \mathrm{~h}$ & Solution treated: & 0 & $8.2 \pm 0.2$ & $17 \pm 2.1$ & $24 \pm 2.0$ & $750 \pm 13.1$ & NA \\
\hline \multirow{3}{*}{ Vacuum } & $720^{\circ} \mathrm{C}-1 \mathrm{~h}$ & 60 & $4.0 \pm 0.4$ & $68 \pm 3.2$ & $75 \pm 3.3$ & $98.1 \pm 8.2$ & $251.6 \pm 4.2$ \\
\hline & Aged treated: & 70 & $3.1 \pm 0.6$ & $72 \pm 3.0$ & $80 \pm 2.7$ & $71.2 \pm 1.1$ & $238.4 \pm 5.1$ \\
\hline & $620^{\circ} \mathrm{C}-8 \mathrm{~h}$ & 80 & $2.5 \pm 0.6$ & $95 \pm 3.5$ & $99 \pm 4.2$ & $11.8 \pm 0.2$ & $41.0 \pm 0.9$ \\
\hline
\end{tabular}

pores was similar to that of the carbamide powder particles. The foams were observed to contain mainly two types of pores: macropores obtained as a result of carbamide space-holder, and micropores on cell-walls, presumably resulting from the compaction and sintering process during the production of the Ni-718 superalloy foam. By adjusting some space-holder particles, the porosity of the resulting Ni-718 foam can be altered. Macropores become directly connected above a porosity of $60 \%$, which may vary with the size of the space-holder particles and the powders constituting the cell walls [22-24].

Figure 5a shows the structure of a typical cell and the cell walls of Ni-718 superalloy foam produced by space-holder technique, which has a carbamide of $80 \%$. The geometry of the cell closely matches that of the carbamide particles used in this study. The interconnecting cell channels are also clearly shown. Figure 5b shows the bonding region between Ni-718 particles in the sample, indicating that strong bonds have formed between the particles. As can be seen in Fig. 5b, the microporosities existed in the sample. The microporosity in the sintered sample should be kept as low as possible if a high-strength porous metal solid were desired. SEM micrographs of the microstructure for selected, heat-treated Ni-718 foams are shown in Fig. 5c. Ni-718 samples exhibit a $\gamma-\gamma^{\prime}$ structure typical of Ni-base superalloys [21, 22]. The Ni-718 foam exhibits $\gamma^{\prime}$ precipitates showing a cuboidal or rod-like morphology with interfaces crystallographically oriented within the $\gamma$-phase matrix.

Figure 6a shows the compressive stress-strain curves of baseline and porous Ni-718 sintered samples with different fractions of carbamide. When the non-porous sample reaches $950 \mathrm{MPa}$ stress (strain $30 \%$ ), the corresponding stress for carbamide-added samples at 60,70 , and $80 \%$ are $211.3,131.8$, and 40.6 $\mathrm{MPa}$, respectively. Figure $6 \mathrm{~b}$ shows the compressive stress-strain curves of baseline and porous Ni-718 sintered and aged samples with different fractions of carbamide. When the non-porous sample reaches $950 \mathrm{MPa}$ stress (strain $30 \%$ ), the corresponding stress values for carbamide-added samples at 60 , 70 , and $80 \%$ are $120.0,101.2$, and $22.5 \mathrm{MPa}$, respectively. Figure 6 shows a common stress-strain behav- ior characterized by three distinct regions (i.e., stress rising linearly with strain at low stresses (elastic deformation), followed by a strong plastic yielding for strains, and then a progressive densification regime where the cell walls come in contact one with another, causing an abrupt rise in the flow stress) [1-6, 16, 25]. Once the cell edges collapse at the yield point, the collapsed edges have little ability to bear the load and bend easily. The deformation mode, resulting from the repeatable failure of the pore layers, gives rise to the uneven character of the stress-strain curve. At the end of the plateau region, stress starts to increase since the pores have flattened and the material attains bulk-like properties. The plateau region has vital importance for the applications requiring energy absorption capability. Compression tests of the porous samples showed that the compressive strength values decreased and length of the plateau region increased with increasing porosity [1, 2, 27-31]. Figure 6c shows a comparison of sintered and aged samples for 80 vol.\%. When compared the sintered and aged samples, strain values of the aged samples are higher than those of sintered samples. Depending on the aging process, elongation of the samples was developed. Table 2 shows the sintering and heat treatment conditions, sintered density and compressive strain (at 600 and $950 \mathrm{MPa}$ ) for porous and fully dense Ni-718 samples processed by PM with the space-holder technique. The carbamide particles decreased the sintered density and increased strain of the porous samples. The strength of the samples was increased with a decrease in porosity.

\section{Conclusions}

Experimental results show that a carbamide pore former, nearly 100-fold larger than the Ni-718 superalloy particles, provides the means to retain large pores in the sintered body. By extraction of the carbamide by water leaching after compaction, medium density Ni-718 superalloy foams are realized by a traditional powder metallurgy route. The green compact had sufficient strength for handling after water leaching at sintering stages. Metallographic studies revealed that the pores were distributed relatively uniform in 
the sintered structure. Large number of micropores formed in the cell walls due to insufficient solid-state sintering. No distortion or other visible reduction in part quality or surface finish was observed at $1265^{\circ} \mathrm{C}$ for $1 \mathrm{~h}$ under vacuum. By comparing the physical and mechanical properties of the samples with the homogeneous porous structure, sintered density decreased, porosity increase with a fraction of space-holder particles increment was observed.

\section{Acknowledgements}

This study was supported by the Scientific Research Projects Coordination Unit of Marmara University, Project number FEN-C-DRP-090512-0172. The authors are grateful to Sandvik Osprey Ltd. for their financial support and the provision of laboratory facilities.

\section{References}

[1] Ashby, M. F., Evans, A. G., Fleck, N. A., Gibson, L. J., Hutchinson, J. W., Wadley, H. N. G.: Metal Foams: A Design Guide. Boston, Butterworth-Heinemann 2000.

[2] Banhart, J.: Prog. Mater. Sci., 46, 2001, p. 559. doi:10.1016/S0079-6425(00)00002-5

[3] Kovacik, J., Jerz, J., Minarikova, N., Marsavina, L., Linul, E.: Frattura ed Integrita Strutturale, 36, 2016, p. 55. doi:10.3221/IGF-ESIS.36.06

[4] Kovacik, J., Simancik, F.: Kovove Mater., 42, 2004, p. 2.

[5] Simone, A. E., Gibson, L. J.: Acta Mater., 44, 1996, p. 1437. doi:10.1016/1359-6454(95)00278-2

[6] Dunand, D. C.: Adv. Eng. Mater., 6, 2004, p. 369. doi:10.1002/adem.200405576

[7] Choe, H., Dunand, D. C.: Acta Mater., 52, 2004, p. 1283. doi:10.1016/j.actamat.2003.11.012

[8] Raj, S. V., Ghosn, L. J.: Mater. Sci. Eng. A, 474, 2008, p. 88. doi:10.1016/j.msea.2007.03.102

[9] Gulsoy, H. O., German, R. M.: Pow. Metall., 51, 2008, p. 350. doi:10.1179/174329008X286703

[10] Pollock, T. M., Tin, S.: J. Propul. Power, 22, 2006, p. 361. doi:10.2514/1.18239

[11] Semiatin, S. L., McClary, K. E., Rollett, A. D., Roberts, C. G., Payton, E. J., Zhang, F., Gabb, T. P.: Metall. Mater. Trans. A, 43, 2012, p. 1649. doi:10.1007/s11661-011-1035-y

[12] Cieslak, M. J.: In: Proceedings of the International Symposium on the Metallurgy and Applications of Superalloys 718, 625 and Various Derivatives. Eds.: Green, K. A., Pollock, T. M., Harada, H., Howson, T. E., Reed, R. C., Schirra, J. J., Walston, S. Warrendale, TMS 1991, p. 679.
[13] Song, K. H., Nakata, K.: Mater. Des., 31, 2010, p. 2942. doi:10.1016/j.matdes.2009.12.020

[14] Conder, C. R., Smith, G. D., Radavich, J. F.: In: Proceedings of Superalloys 718, 625, 706 and Various Derivatives. Ed.: Loria, E. A. Warrendale, TMS 1997, p. 1025.

[15] Zhao, Y. Y., Sun, D. X.: Scripta Mater., 44, 2001, p. 105. doi:10.1016/S1359-6462(00)00548-0

[16] Bakan, H. I.: Scripta Mater., 55, 2006, p. 203. doi:10.1016/S1359-6462(00)00548-0

[17] Jiang, B., Zhao, N. Q., Shi, C. S., Li, J. J.: Scripta Mater., 53, 2005, p. 781 . doi:10.1016/j.scriptamat.2005.04.055

[18] Bram, M., Stiller, C., Buchkremer, H. P., Stover, D., Baur, H.: Adv. Eng. Mater., 2, 2000, p. 196. doi:10.1002/(SICI) 1527-2648(200004)2:4<196:: AID-ADEM196> 3.0.CO;2-K

[19] Queheillalt, D. T., Hass, D. D., Sypeck, D. J., Wadley, N. G.: J. Mater. Res., 16, 2001, p. 1028. doi:10.1557/JMR.2001.0143

[20] Sypeck, D. J., Parrish, P. A., Hayden, H. N. G.: In: Materials Research Society Symposium Proceedings. Eds.: Schwartz, D. S., Shih, D. S., Wadley, H. N. G., Evans, A. G. Warrendale, MRS 1998, p. 205.

[21] Ozgur, O., Gulsoy, H. O., Yilmaz, R., Findik, F.: J. Alloys and Comp., 576, 2013, p. 140. doi:10.1016/j.jallcom.2013.04.042

[22] Choe, H., Dunand, D. C.: Acta Mater., 52, 2004, p. 1283. doi:10.1016/j.actamat.2003.11.012

[23] Michailidis, N., Stergioudi, F., Tsouknidas, A.: Mater. Sci. Eng. A, 528, 2011, p. 7222 . doi:10.1016/j.msea.2010.10.088

[24] Michailidis, N., Stergioudi, F., Tsouknidas, A., Pavlidou, E.: Mater. Sci. Eng. A, 528, 2011, p. 1662. doi:10.1016/j.msea.2010.10.088

[25] Michailidis, N., Stergioudi, F.: Mater. Des., 32, 2011, p. 1559. doi:10.1016/j.matdes.2010.09.029

[26] Li, B. Q., Yan, F., Lu, X.: Mater. Sci. Eng. A, 534, 2012, p. 43. doi:10.1016/j.msea.2011.11.028

[27] Bekoz, N., Oktay, E.: Mater. Process. Tech., 212, 2012, p. 2109. doi:10.1016/j.jmatprotec.2012.05.015

[28] Kohl, M., Habijan, T., Bram, M., Buchkremer, H. P., Stover, D., Köller, M.: Adv. Eng. Mater., 11, 2009, p. 959. doi:10.1002/adem.200900168

[29] Bansiddhi, A., Dunand, D. C.: Mater. Eng. and Perf., 20, 2011, p. 511. doi:10.1007/s11665-010-9827-6

[30] Mutlu, I., Oktay, E.: Mater. Sci. Eng. C, 33, 2013, p. 1125. doi:10.1016/j.msec.2012.12.004

[31] Mutlu, I., Oktay, E.: Mater. Des., 44, 2013, p. 274. doi:10.1016/i.matdes.2010.09.029 